\title{
THE MEANING OF REBBE RITUAL AS AN INTERPRETATION OF SHADAQAH JARIYAH IN PROBOLINGGO
}

\author{
Danial Hilmi and Halimatus Sa'diya ${ }^{2}$ \\ ${ }^{1}$ FITK UIN Maulana Malik Ibrahim Malang \\ ${ }^{2}$ Faculty of Psychology UIN Maulana Malik Ibrahim Malang \\ Email: danialhilmi@gmail.com
}

\section{Abstract}

The community of Lemah Kembar Village has a form of local wisdom preserved in fostering relationships, not only about the living but also about people who have passed away through shadaqah jariyah. One way of the cultural wisdom is the rebbe ritual done by the Probolinggo community, which is seen as alms from living families to relatives who have passed away. This study focused on exploring community interpretations and the historical social construction of rebbe ritual in interpreting the meaning of shadaqah jariyah in the community of Lemah Kembar village, Sumberasih district, Probolinggo. The results revealed that the historical social construction of rebbe ritual emerged from the differences of community's understanding about the shadaqah jariyah, which were grouped into three, namely the group of people who believed in rewarding the deceased, the students who carried out the tradition but interpreted it differently, and the students who refused to do the tradition because such rituals were considered contrary to Islamic teachings.

Masyarakat Desa Lemah Kembar memiliki suatu bentuk kearifan lokal yang dilestarikan dalam membina hubungan tidak hanya dengan orang yang hidup, tetapi juga dengan orang yang telah meninggal melalui shadaqah jariyah. Salah satu bentuk kearifan budaya tersebut diantaranya adalah ritual Rebbe yang merupakan salah satu tradisi lokal masyarakat Probolinggo yang dipandang sebagai sedekah dari keluarga yang masih hidup kepada sanak kerabat yang 
sudah meninggal. Kajian ini menitikberatkan pada eksplorasi masyarakat dan konstruksi sosial historis ritual Rebbe dalam menginterpretasikan makna shadaqah jariyah pada masyarakat Desa Lemah Kembar, kecamatan Sumberasih, kabupaten Probolinggo. Adapun hasil penelitian ini adalah bahwa konstruksi sosial historis ritual Rebbe berangkat dari perbedaan pemahaman masyarakat tentang Shadaqah Jariyah yang bisa dikelompokkan menjadi tiga, yaitu kaum awam yang meyakini akan sampainya hadiah pahala kepada orang yang meninggal, kaum santri yang menjalankan tradisi namun memaknainya secara berbeda, dan kaum santri yang menolak sama sekali untuk melaksanakan tradisi tersebut lantaran ritualnya dianggap bertentangan dengan ajaran Islam.

Keywords: Rebbe Ritual; Interpretation; Shadaqah Jariyah

\section{Introduction}

Indonesian Islamic culture is full of characteristics and distinctive identity with various rituals and practices which combine traditional teachings with the arrival of Islamic teachings. The combination is very thick with the typical nature of the archipelago that distinguishes it from what is found abroad, especially in the Middle East. Yet, it cannot be denied that Islam has experienced its glory in Indonesia.

Al-Qur'an and al-Hadith are the primary sources of Islamic religion and life guidance for every Muslim. As the religion of rahmatan lil 'Alamin, al-Qur'an and al-hadith explain a lot about the virtues of doing good to others, such as zakat, infaq and the offer of shadaqah mentioned in the Holy Qur'an (QS. 57: 18). In al-Quran surah Al-Zalzalah verses 7-8, it is explained that every good and bad deed has its rewards. Shadaqah jariyah is the activity of sharing with others to draw a closer and unconditional relationship with Allah SWT. It is carried out because of one's obedience and faith to Allah SWT. The activity is not only limited to sharing materials but also doing a good deed to others.

One of the local wisdom of the Javanese people is "ater-ater" tradition or sharing food with relatives, friends, or neighbors. This tradition is still heavily preserved until now, especially when commemorating religious holidays such as Maulid Nabi, Isra' Mi'raj, Qurban holiday, Eid al-Fitr, and so forth. The community interprets ater-ater tradition as the simplest form of alms.

Regarding the virtues of alms, Muslim communities in Java often associate them with the term shadaqah jariyah. The alms worth an unbroken reward is called jariyah. Thus, the merit of good deeds in the form of alms 
can be given to families who have passed (Zuhaili, 1997). The debate over the benefits of those who provide the reward for the deceased relatives has taken place centuries ago.

The traditions that are hereditary among Indonesian people contribute to the diversity of ways of behaving and responding to every event and life experience that becomes a part of the local culture. The traditions do not stand-alone because strong internal, social, and religious impulses often become the main considerations to conduct certain rituals. It has also been experienced by the Probolinggo community in addressing the importance of sadaqah jariyah as an effort to carry out the religious message, especially for families who have passed away.

Probolinggo is an area located in the eastern part of East Java province, which is also known as Tapal Kuda city. The majority of Probolinggo people are Muslims except for a small number of people living in Bromo mountain. The rebbe ritual is one of the local wisdom of Probolinggo community, which is a form of alms from living families to the deceased relatives conducted at home or grave of the deceased. The alms are done in the form of giving staple foods such as rice, side dishes, fruit, and various snacks to relatives, closest neighbors, or families who cannot afford the foods. Rebbe is carried out at certain times such as Friday night, Monday night, the birthday of the dead, and religious holidays.

The people of Probolinggo commonly practice this ritual. Even in certain areas, the ritual is also done by communicating with the spirits of the deceased. The peak of the ritual usually takes place on the night of $10^{\text {th }}$ Suro (Muharram month). In this ritual, the reward of alms is not only delivered to one person who had passed but also devoted to all families who had passed while mentioning the names of the deceased based on a family tree (observation result of rebbe ritual in Mr. Juhri's house on November 5, 2018).

Rebbe ritual is significant to study because of some reasons. First, it is a tradition that elevates Islamic values in the concept of alms to send commended good deeds. Second, it preserves the wisdom of Javanese culture to share food so that close family relations are established. Finally, the ritual preserves Madurese culture in introducing a kinship system to ancestral lines to the younger generation.

There are some previous studies relevant to this present research. The research conducted by Holis (2017) analyzed the phenomenon of charity seekers (donations) for the construction of mosques on the street. The donation 
seems to run based on the absolute work ethic that must be done so that it becomes an agreement of a group of people and becomes a social symbol that is difficult to change. In addition, Danel (2015) analyzed the ceremony done by Mukad Ulid Dayak Bulusu tribe for people who had died as a form of respect for the ancestors. The ceremony is considered as the termination of the inner connection between the family of the deceased and the person who died, so that the family is away from harmful things. It is done as the ceremonial delivery of the spirit to the eternal realm called londoyon.

Based on the studies above, it can be concluded that the first study focused on people or actors who did amal jariyah, while the second was pivoted on the mukad ulid ritual which preserves cultural heritage to honor ancestors who had died by perpetuating the carried message. Meanwhile, the present research focuses more on how rebbe ritual is carried out in connection with the concept of sadaqah jariyah which is taught in Islam but contained traditional beliefs.

This tangible social reality has been going on for centuries. Therefore, rebbe ritual has its special meaning for Probolinggo people. As one form of local cultural wisdom, the ritual is interesting to investigate because it elevates Islamic values in giving alms to the society. Besides, it is also included in the recommended good deeds and efforts to preserve Javanese cultural wisdom. Finally, it will preserve Madurese culture in introducing a kinship system to the younger generation.

\section{Method}

This study used field research to explore phenomenological field data regarding the procession and meaning of the rebbe ritual in Probolinggo community about shadaqah jariyah. The approach used was qualitative research because this research focused more on extracting data directly to key informants.

This study consisted of the villagers of Lemah Kembar, Sumberasih Probolinggo regency consisting of four hamlets, namely Tanah Merah, Kalisat, Parus, and Bibis. In this case, the researcher acts as a key instrument in gathering and analyzing the data.

The data covered the process of rebbe ritual activities, key information related to the meaning, history, and development of the ritual as well as the community's view of shadaqah jariyah. It also covered how the villagers understood its meaning which became the meeting point of the community's shadaqah jariyah concept in the community. 
The data were gathered from the community leaders, religious leaders, all citizens as performers of the rituals, and various reference books that described the practice of shadaqah jariyah and forms of social construction in the community. The data collection and extracting techniques used were interviews, observation, and document study. Meanwhile, the data analysis technique varied from domain analysis, taxonomic analysis, componential analysis, to cultural theme analysis.

This study used a historical social approach. According to Kuntowijoyo (2003), a phenomenon that occurs in a community will become a part of life in the community itself. The historical social concept is the writing of history which makes society the subject of a study. In this case, a business that can create a comprehensive framework for the whole community is needed.

To gain a full explanation of the meaning of rebbe ritual, this research also referred to the study of anthropology. One of the most important keys of the study is holism, namely the view that social practices must be examined in context and essentially seen as practices related to others in the community (Gellner, 2002). In this case, the study of phenomena should look at the relation of religion to other aspects that may emerge as a reflection of reality. The culture in the society certainly has a background as a part of meaningful social interaction for their life.

\section{Various Meanings of Shadaqah Jariyah for Lemah Kembar Community}

As a pluralistic nation, Indonesia has two kinds of cultural systems, namely national and local ethnic cultural systems. The national cultural system is relatively new and is still in the process of formation. This system generally applies to all Indonesians, but at the same time is outside the boundaries of any local ethnic culture. These values become a sense of Indonesia because they are combined with other values that are derived from old cultural values contained in various local cultural systems (Basri, 2011).

The integration of culture in the identity of the Indonesian nation exists in daily routines through manifestations of behavior that is recognized by the plural society, as well as to be developed and deepened in the local culture. In the meantime, one form of cultural fusion is the tradition of shadaqah, which does not come initially from practices and actions that exist in any community. Thus, the practice of shadaqah often becomes an urgent matter to instill by religious leaders to avoid misunderstanding in society. 
The word shadaqah comes from the word "shadaqa" which means true. In this case, the word can be interpreted as those who like to give alms are "those who confess his faith". According to fuqoha, shadaqah is a Muslim gift to his Muslim brother/sister and is considered a virtue that expects Allah's blessing and mercies (Wardana, 2018).

Shadaqah is the activity of sharing with others as an attempt to be closer to Allah SWT and is carried out because of a Muslim's obedience and faith to Allah SWT. People who give alms are convinced of the promise of Allah who gives sustenance to each of His creations. For people who understand the true meaning of alms, their belongings will be taken care of only in the path blessed by Allah (Wardana, 2018). Meanwhile, shadaqah jariyah is an attempt from a servant to gain closeness to his God, with the hope that other people can take advantage of his shadaqah all the time. Even though he is gone (dead), he will still receive his reward (Syukri, 2011).

The community of Lemah Kembar village, Sumberasih district, Probolinggo is a community known to have a close relationship with relatives, which is still well conserved until today. They also hold a belief that they should routinely share shadaqah jariyah. The purpose of sharing the shadaqah to those in need is that they can deliver the reward to the deceased.

The essential aim of shadaqah is to create harmony in social life as well as to create awareness to do good even if it starts with small things. With shadaqah, humans are taught to have unconditional and sincere feelings, and have empathy for others (Wardana, 2018).

According to the local religious leaders in Probolinggo, shadaqah jariyah is a pious act in the form of giving alms in which the value of the reward is unbroken even if someone has died. The rewards for those who are still alive can continue to increase along with the pious deeds performed. Whereas for those who have died, the merit of shadaqah jariyah can still be sent to the deceased by the relatives who are still alive by specializing the merit of shadaqah for those who passed away or mayyit.

The people of Lemah Kembar village unwittingly agree that the reward of shadaqah jariyah is devoted to mayyit of the living relatives. Such conditions are often experienced by ordinary people who base their understanding of their parents or ancestors that occur in a hereditary way without trying to study the cleric of shadaqah jariyah intensively.

Every deed done by someone will surely receive a reward. Every person who does good will be rewarded with kindness and merit, whereas those who 
do bad will be tormented. God gives humans obligations and responsibilities according to their abilities; therefore, naturally, the reward commensurate with the deeds done. Allah is the most gracious because goodness done by humans get a ten-time reward (Anies, 2009).

For students who study at pesantren and often go home to meet their parents, they are commonly influenced by the information that their parents get from lectures obtained from television. This is risky because pesantren is supposed to be the primary source of getting religious knowledge, instead of being dominated by an understanding that comes from parents. Their understanding is based on hereditary beliefs coming from their ancestors without being equipped with authentic propositions.

The implementation of almsgiving of the earth contains several elements. It can be seen as useful, such as the creation of an atmosphere of togetherness and brotherhood, the creation of an atmosphere of cooperation, and the establishment of the soul sacrifice. These values in principle do not conflict with Islamic values. However, the earth alms ceremony also contains elements that are contrary to Islamic teachings, and sometimes include acts of shirk (Hidayatulloh, 2013).

The understanding of not reaching the reward of shadaqah jariyah for people who have died has an impact on the behavior or participation of the students in carrying out cultural rituals that are carried out in the local community. In the meantime, this second group's understanding only excludes prayers intended for people who have died with the reward of passing through that route.

The pattern of implementation of shadaqah jariyah that applies among the people of Lemah Kembar village has a characteristic that the reward is delivered to people who have not received facilities from the prayer interpreter or sent the reward. Many charity fundraisers are found for the construction of mosques, small mosques or places of education in the form of giving out an amount of money voluntarily without being limited. This activity is carried out on the roadside, which is the main road for residents to pass.

As has been explained before related to the community's interpretation of shadaqah jariyah, which is intended for people who have died have a variety of different views. This is based on the differences in the interpretation of the propositions used and the role of the hereditary ancestors who have carried out traditions that run in the community. Based on this, the differences can be classified as follows.

el Harakah Jurnal Budaya Islam Vol. 22 No. 1 Tahun 2020 
First, most community members interpret shadaqah jariyah as a form of amaliyah whose reward continues to flow even if someone dies. Besides, this group believes in the gift of shadaqah jariyah reward in the form of food and prayers offered to people who have died as taught by their ancestors.

Second, a part of the santri community defines shadaqah jariyah as a form of giving whose reward is unbroken even if someone dies. Meanwhile, this group believes in the gift of shadaqah jariyah reward to relatives who had died known from the clerics or religious teachers but without knowing in depth truth of the lecture.

Third, a small group of the santri community defines shadaqah jariyah's reward that will last only as long as the person is still alive in which deeds can be rewarded if someone does good deeds. This group's understanding is based on hadith that if someone dies, then the deeds are cut except for three cases, i.e. alms giving, useful knowledge, or the prayers of a pious child (HR. Muslim no. 1631).

The implementation of shadaqah for the poor can function as a gift given by Allah to His servants. The rich as an intermediary will distribute every asset he has because that is his right. In the teachings of Islam, many ways can be done to make shadaqah, for example in the form of material, services, or smiles. In Indonesian society, the tradition of giving alms is not only for those who are still alive, but also for family members who had died, even the predecessors in their respective villages. This tradition is known as almsgiving of the earth.

The Islamic view of the arrival of shadaqah jariyah brings to its adherents how safe it is to live in an Islamic state. Moreover, the guarantee of heaven and a decent place will bring fresh air for every Muslim who carries out worship, especially to give alms to others. Some of the worships and obedience can bring benefits to those who have died. The worship can be done in the form of human obedience during life in the world or efforts from others to people who had died (Syukri, 2011).

In the meantime, the gift of reward is only limited to sending prayers to both parents or people who had died with nothing to do with offerings that are used as a means to convey the reward. As the tradition of sending prayers in the community is done purely to pray for people who had died in the grave, but it is not a "blessing" which means sending prayers or giving alms to relatives who are often carried out by all people. 


\section{The Meaning of Rebbe Ritual for Lemah Kembar Community}

Rebbe is one of the cultural practices of Lemah Kembar village communities passed from generation to generation. It is the result of acculturation of local culture, religion and myths. Practicing a plurality of rhythms in the local community makes the long-term preservation of rebbe culture.

Associated with the tradition that runs in the area, the social construction in understanding the meaning of shadaqah jariyah on residents has different characteristics and patterns. The relationship between people who are still alive with people who have died is intertwined if a glimpse of newcomers presents in that environment.

Historically, Lemah Kembar villagers have performed rebbe ritual for generations, but there are no detailed historical records related to the beginning of the ritual carried out by the community. Therefore, it can be concluded that the villagers only continue the ritual practice without knowing the exact meaning behind the tradition.

Meanwhile, the village religious leaders explained that the beginning of the ritual implementation was based on local beliefs. The ritual has been ingrained in the villagers for many years, but it is not known exactly when and who started it. In the meantime, even the elders did not know for sure, although they have lived for many periods.

According to some circles, the ritual can be regarded as a myth that was spread orally and passed down from one generation to the next generation as a story or something said by the ancestors. Thus, rebbe can be told as a story that has become a belief and has a sacred meaning for the people of Lemah Kembar village, especially in carrying out the myths and constructions that are difficult to change. The people who do not have enough scientific knowledge about this tradition will continue to do it without questioning the origin of the tradition.

The form of social construction that perpetuates the tradition of rebbe ritual in the community of Lemah Kembar is the belief that the reward of shadaqah jariyah is given to relatives who died so that the ritual becomes a mandatory tradition that cannot be separated from the life of the villagers. Shadaqah jariyah pattern is carried out in the form of rebbe ritual combined with a myth that has been developed over time. Consequently, there is a shift of motives behind the ritual practice. The recent motives of conducting the ritual might be different from that of the pioneers. 
In various rituals, commonly there is a connection between the system's symbol, social cohesion, and social transformation. Likewise, there are two forms of religious rituals in Islam, namely, official and local or popular rituals. One of the death rituals well known in Javanese society is tahlilan. In this ritual, the family of the deceased invite relatives and neighbors to recite tahlil and other dhikr while providing shadaqah in the food that is offered to the guests (Mulyadi, 2013: 129).

The community considers rebbe ritual to be a mandatory tradition that must be carried out even more, to be done even if they are going to do other activities. Thus, serving parents becomes an obligation and an important thing to do other than doing daily activities. This is also because people who have died have been waiting for shadaqah jariyah to be sent to them from their relatives who are still alive.

The social construction of rebbe ritual appears as a relationship between myths and symbols in a religious society. Islam as the only religion that is adopted by the people of Lemah Kembar village has several virtues of shadaqah jariyah. The virtues are understood and realized through the ritual's activity, which is believed to be able to deliver shadaqah jariyah gifts from living families to relatives who have died. This is based on their belief that shadaqah jariyah means a form of shadaqah whose reward can be continued even if someone has died. Thus, the living relatives can still send the reward of shadaqah jariyah for relatives who have died.

\section{The Historical Social Construction of Rebbe Ritual in Interpreting the Meaning of Shadaqah Jariyah}

Social construction is a new theory of sociology from Berger and Luckmann (2016). This theory contains two keys, namely reality and knowledge as the two things that are built socially. The reality is various phenomena that exist without depending on human will, while knowledge is real or unreal, and its existence has its characteristics (Manuaba, 2008).

The meaning of each view refers to how the knowledge is obtained and how to process it in a thought that is following the conditions of the local community. Furthermore, the meaning will bring subjectivity in building a whole concept by trying to make it a basis on every step to create a diverse interpretation among the local community. That way, various efforts are made for the creation of good relations. 
The theory developed by Berger and Luckmann is the sociology of knowledge based on the reality of everyday life in society (as cited in Jackson, 2012). Berger \& Luckman (2016) also argued that the reality of everyday life is not real. It is exhausted by the immediate presence, but embraces phenomena that are not present in 'here and now'. It means that each experiences everyday life in terms of differing degrees of closeness and remoteness, both spatially and temporally.

A life filled with an environment based on everyday contexts will make the surrounding community involved in every initiated ritual. It means that each event in life is processed into a ritual that will lead to a decline in the inheritance. It inevitably will be passed on to the next generation who demands human relations through objectivity in acting.

In this theory, there is a dialectical process consisting of things, namely externalization, objectification, and internalization. Externalization is a process exists in a person and is then devoted to social reality. The objectification is a product that comes from deep thinking in the real form whose results can be felt by reality. The internalization is something that has been conveyed out then included in the self and interpreted deeply (Na'im, 2017).

The reality of life becomes a benchmark of subjective truth and brings a different impression to others. The reality experienced by people from generation to generation has been systematically arranged so that it cannot be traced since when and how the event began. This is where historical study emerges as a form of tracking of every ritual performed by a group of people in realizing the same feeling.

Berger and Luckman (2016) argue that the reality in daily life is continuously organized. In this case, all phenomena are arranged in various patterns that do not depend on one's understanding. Moreover, according to Berger and Luckman, this life contains objectivities, and signs or symbols. It will not be separated from the existence of history or history that descends on the human mind. One of the various signs and symbols that appear in everyday life is language. Language can save the objectivity of meaning from various phenomena and be able to preserve it from one generation to the next.

An event or phenomenon that occurs in society will become a part of life in the community itself. If the phenomenon or event is reviewed, history will be known. The historical social concept is the writing of history which makes society a subject of study. In this case, a business that can create a comprehensive framework for society as a whole is needed (Kuntowijoyo, 2003). 
Every ritual that is developed in the community certainly cannot be separated from the history that underlies it, whether it is based on mutual agreement or the existence of a myth that is believed to be able to resolve matters. Therefore, a ritual will reflect how the condition of the community at the beginning of the activities that exist in the next era seems to be far from the rational principle.

The word ritual comes from the word rite. There are various definitions of ritual. According to the Indonesian dictionary (KBBI, 2002), the meaning of ritual is a matter of procedure in religious ceremonies. According to Koentjaraningrat (n.d.), the ritual is a special or sacred ceremony performed by religious people. In this activity, there is a place, time, tools, and participants participating in the event.

The existence of rituals for humans is a symbol of religion and human culture. Such symbolic actions become a necessity because humans must communicate with God Almighty. These ritual activities are carried out from generation to generation to maintain certain rituals (Budiyono, 2001).

Shadaqah jariyah as a part of religious guidance to give away some of one's property has become an undeniable thing in carrying out religious orders. In the meantime, the agreement established by the ancestors often becomes a tradition passed down to the next generation whose meanings are sometimes unknown as expected by the pioneers.

Indonesian society is inseparable from the beliefs of dynamism and animism that have existed for a long time. Thus, the ritual has become one of the cultures carried out by the community. In Java, including East Java, religious rituals are commonly performed to avoid evil things. From the rituals, people ask the spirit not to disturb them or to bless them (Darori, 2002). Thus, for some group of people, ritual activities are considered negative because they are related to mysticism.

Symbolic representation of shadaqah jariyah's pattern prevailing in the community forms awareness and a basic understanding of the ritual for all residents. In the meantime, mutual agreement within the framework of togetherness is based on language, art, history, religion, and the social environment that can be a foothold in acting. Many things affect the implementation of a ritual that will outline the resolution of a problem that is experienced by both individuals and groups.

The meaning of symbolic reality forms a pattern of social construction that is depicted from a community tradition. On the historical social construction 
process in interpreting the meaning of shadaqah jariyah, three processes accompany the stages of the pattern, namely objectivities, externalization, and internalization.

The objectivities and externalization stages are the formation of a society called primary socialization. It is the moment when the ritual gets recognition from the community after it is initiated and done massively for the creation of a form of social construction that is prevailed among the local community. In this stage, the people of Lemah Kembar village face objective reality and take action on what they experience and act as a form of self-realization.

While the internalization stage requires social institutions to be maintained and continued, there must be a justification for the social institutions. Yet, it should be noted that humans themselves through a process of legitimacy called secondary objectivities made the justification. In the form of legitimacy, there are special nights considered as sacred moments to send a reward of shadaqah jariyah to families who have died, namely Monday night and Friday night.

Internalization of rebbe ritual as a part of historical social construction illustrates that shadaqah jariyah goes down through generations. It is an embodiment of community understanding in the form of rituals traditionalized in shaping interactions and patterns of life together. This social construction describes expressions and patterns of primitive solutions from agreements that exist in social reality.

Related to the form of the social construction of Lemah Kembar village community in the form of internalization of rebbe ritual, there is an understanding that the tradition is applied as a form of interpretation of the historical conditions that contributes to shaping the pattern. Reward prizes given in the form of shadaqah jariyah are carried out routinely by providing food to relatives and villagers to give prayers. The reward is sent explicitly to families who have died.

In some santri's communities who perform rebbe ritual, drinks prepared should not always be coffee but can also be replaced by tea or mineral water. Meanwhile burning kemenyan is not considered necessary for these communities. In addition, these communities believe that the provision of food and drink that reflect shadaqah jariyah has a reward value given to people who have died.

The use of frankincense in rebbe ritual becomes an even recommended mandatory due to efforts to deliver the reward to the unseen world as used by shamans, psychics and others. Meanwhile, the use of incense in the ritual is undoubtedly contrary to Islamic law.

el Harakah Jurnal Budaya Islam Vol. 22 No. 1 Tahun 2020 
Similar to other rituals carried out in other areas in Java Island, rebbe ritual also has a variety of deep and specific symbols. The Javanese themselves are born with full of symbols that carry meaning every performing ritual; therefore, the culture that is born is also full of symbols. Javanese belief offers a variety of symbols from simplistic to complex. In this context, Siti Nurlaili (2009) stated that Javanese is a man who is rich in symbols. Symbols are not words, but rather an object that is representative of a meaning. Throughout the history of human Java, symbols have colored behavior, language, science, and religion. The function of the symbol is as a medium to convey the message smoothly. Sometimes, the symbol is something complicated, so that only humans who have more knowledge (linuwih) will be able to understand all forms and purposes. The classic Javanese proverb says "wong Jowo iku nggoning semu, sinamuningsa mudana, sesadone ingadu manis". That is, Javanese people place symbols, everything is disguised as symbols with the intention that everything looks beautiful and sweet.

Expressive and communicative symbols are manifestations of rituals. The threat to local wisdom through the swift currents of modernization can be dammed through the interpretation of rituals which have an essential role in maintaining the culture in society. The spiritual relationship between man and his God can be expressed through the behavior that exists in the traditions of religions as a ritual. The experience of one's faith and aesthetics that is sacred in every celebration and ceremony held regularly is also considered a ritual (Ilahi, 2017).

The implementation of a ritual can be held by followers of certain religions or activities carried out steadily by certain communities in the community. Activities carried out in the ritual, cannot be done in vain, but must be by the standard or rules that have been determined. The examples of the rituals are salvation ceremonies, ceremonies for blessing, offerings to be far from the unseen evil, processions, and religious ceremonies.

Trust in ancestral traditions is still widely found and practiced by people in various parts of Indonesia. In the Bugis community in South Sulawesi, for example, such practices are still found. Community appreciation of ancestral mythology and belief in supernatural beings or animals that have supernatural powers is still maintained. However, in some places, especially in urban communities, such beliefs have been lost (Rais, 2010).

In religion, there are also rituals in the form of celebrations that are usually relevant to the people who uphold the values of the ancestors' local 
wisdom. Besides, the ritual also functions as social control, which according to anthropologists is the way the ritual of religion aims to strengthen the tradition of social tied among individuals.

In religion, rituals are framed in the symbolization of local wisdom shown at the annual ceremonial as a holy experience expressed through respect for the ancestors. Religious traditions that contain holy experiences, actually have spiritual mystical values conveyed through the symbol of rhythm. The truth of religion and devotion to the creator can also be presented by utilizing this moment of tradition and local culture. The construction of symbols in a tradition among the community illustrates the pattern of interaction between residents and people, and communication between them in the form of giving shadaqah jariyah practiced in rebbe ritual.

In general, this tradition is not much different from the salvation ritual done by the Javanese people by praying before giving food and drink in the form of "blessing" which becomes a local tradition. The difference between both rituals is that the implementation of the praying ceremony is accompanied by burning incense as a link with the supernatural world.

Rebbe ritual procession in some communities is combined with animism and dynamism beliefs such as calling out the name of the deceased while inviting a chat as if the spirit of the deceased was present. This has the meaning that all efforts to give shadaqah jariyah can be carried out in this form while still paying attention to each other's beliefs.

Meanwhile, when santri performs this ritual, basmalah and al-fatihah in the form of tawassul to the Prophet Muhammad Saw and Shaykh Abdur Qadir Jaelani are added before starting the ritual. This is a symbol of piety to God to ask for the realization of the intended purpose of performing the ritual. Implementation like this is no different than the custom of reading prayers in general, which is often done by all the local communities in Indonesia.

Javanese society with its culture is firmly attached to a belief that is full of mythology, sacredness, and mystification. All of them are mythologies that can be found in people, places, times, and events of the society. Furthermore, the mythologies are seen in names, births, times, letters, numbers, and luck. The Javanese myth's reality is manifested through the form of ritual ceremonies (Fitri, 2012).

The view of religious rites becomes a separate pattern in interacting and giving manifestation to everyday events and activities. In essence, it is to carry out religious rituals that are interpreted together to illustrate the performing 
of shadaqah jariyah. The tradition can be passed down to future generations so that the pioneers also receive the reward as the initiators of the ritual.

The implementation of a religious ritual within the frame of historical social construction places the pioneer to determine the right place and time to practice what one believes. Therefore, all activities will determine when and where a tradition can be carried out. It is the same as Friday prayers, for example, which can only be held in a mosque or near a building that reflects a lively atmosphere. In the meantime, the ritual is also related to the time and place that is used as a place to pour all the interpretation of one's religion.

Aside from celebrating greatness, a ceremony is also explicitly performed to send reward for relatives who have died. This ceremony also aims to invite the deceased to celebrate the ceremony carried out while he or she is still alive. It is possible to get a blessing together.

The time of the procession of rebbe ritual forms a belief in the reward of the deceased by adding incense to the laypeople or abangan so that their belief can be seen from the ritual practice. There is a difference in the chosen time of carrying out the ritual. On Friday night the procession is done at home, then the food is delivered to relatives and closest neighbors. Meanwhile, if the ritual is carried out on religious holidays, then it is conducted at home and the food is delivered to the mushalla to be eaten together by anybody who is present there. According to custom, rebbe ritual is carried out at the home of people who have the intention to send a reward to their passing relative. This tradition is common among Javanese people and is usually accompanied with incense burning.

Myths and symbols in rebbe ritual have a close attachment and have full meaning and symbolic interaction. The symbolic interaction perspective helps understanding human behavior from the subject. This perspective suggests that human behavior should be seen as a process that enables humans to shape and regulate their behavior by considering the expectations of others who are their interaction partners (Ahmadi, 2008). This is a form of action carried out in the form of continuous joint actions under stable conditions and at the same time realized cultural values.

\section{Conclusion}

In realizing the content interpretation of the Qur'an and Hadith, the social community requires patterns in practicing what is believed and understood. In the meantime, the concept of shadaqah jariyah, which has become a religious 
suggestion, has various interpretations in the community, especially in daily practice. In recent times, Lemah Kembar community are divided into three groups in terms of understanding shadaqah jariyah's meaning. First is a group of most ordinary people who interprets it as a form of shadaqah whose reward continues to flow even though someone dies. The second group is some strict Muslims who interprets it as a form of shadaqah whose reward does not stop even if someone dies. The third one is a small group of strict Muslims who defines it as a form of shadaqah that lasts as long as the person is still alive and that deeds can be rewarded if someone is doing good deeds.

Meanwhile, the historical social construction of rebbe ritual in the community of Lemah Kembar village can tbe grouped into two. They are a community who considers the ritual as an obligation and those who consider the ritual as something optional according to the situation and conditions. This tradition is descending from time to time with the belief in the prize reward and is a symbolic communication between people who are still alive and people who had died with treats in the form of incense as a medium. It forms a real understanding of the existence of a tradition that will be sustainable with the same structure carried out among the people of Lemah Kembar village.

\section{References}

Ahmadi, D. 2008. Interaksi Simbolik: Suatu Pengantar. Jurnal Mediator 9(2), https://doi.org/10.29313/mediator.v9i2

al-Zuhaili, W. 1997. Al-Fiqh al-Islamy wa Adillatuhu. Damascus: Dar al-Fikr. Cet. IV. Juz. 2

Anies, M. M. 2009. Tahlil dan Kenduri: Tradisi Santri dan Kiai. Yogyakarta: Pustaka Pesantren.

Basri, M. H. 2011. Ritual Ya Qowiyu: Pergulatan Makna Modernitas, Agama, Budaya Lokal dan Kapitalisme. El-Harakah, 11(2), 99-104. https://doi. org/10.18860/el.v0i0.426

Berger, P., \& Luckmann, T. 2016. The Social Construction of Reality. Social Theory Re-Wired: New Connections to Classical and Contemporary Perspectives: Second Edition, 110-122. https://doi.org/10.4324/9781315775357

Budiyono, H. 2001. Simbolisme Dalam Budaya Jawa. Jakarta: Prasetya Widya Pratama.

el Harakah Jurnal Budaya Islam Vol. 22 No. 1 Tahun 2020 
Darori, A. 2002. Islam dan Kebudayaan Jawa. Yogyakarta: Gama Media.

Faizal, A. 2014. Makna Simbolik Dari Tradisi Sajen Among-among Dalam Memperingati Kematian (Studi Pada Masyarakat Desa Lamongrejo, Kecamatan Ngimbang, Kabupaten Lamongan). Surabaya: UIN Sunan Ampel.

Fitri, A. Z. 2012. Pola Interaksi Harmonis antara Mitos, Sakral, dan Kearifan Lokal Masyarakat Pasuruan. El-Harakah, 14(1), 1-17. https://doi. org/10.18860/el.v0i0.2198

Gellner, D. N. 2002. Pendekatan Antropologis. Dalam Peter Conolly (ed.), Aneka Pendekatan Studi Islam. Yogyakarta: LkiS

Hidayatulloh, F. S. 2013. Sedekah Bumi Dusun Cisampih Cilacap. El-Harakah (Terakreditasi), 15(1), 1. https://doi.org/10.18860/el.v15i1.2669

Ilahi, M. T. 2017. Kearifan Ritual Jodangan dalam Tradisi Islam Nusantara di Goa Cerme. IBDA`: Jurnal Kajian Islam dan Budaya. 15(1), 42-58. https://doi.org/10.24090/ibda.v15i1

Kamus Besar Bahasa Indonesia 2002

Karman. 2015. Konstruksi Realitas Sosial Sebagai Gerakan Pemikiran (Sebuah Telaah Teoretis Terhadap Konstruksi Realitas Peter L. Berger). Jakarta: Balai Pengkajian dan Pengembangan Komunikasi dan Informatika (BPPKI) Badan Litbang SDM Kemenkominfo

Kuntowijoyo. 2003. Budaya dan Masyarakat. Yogyakarta: Tiara Wacana.

Manuaba, I. B. P. 2008. Memahami Teori Konstruksi Sosial. Jurnal Masyarakat Kebudayaan dan Politik Fakultas Ilmu Budaya Universitas Airlangga 21 (3). $221-230$

Muhaimin. 2012. Studi Islam Dalam Ragam Dimensi dan Pendekatan. Jakarta: Kencana Prenada Media Group.

Mulyadi, A. 2018. Memaknai Praktik Tradisi Ritual Masyarakat Muslim Sumenep. Endogami: Jurnal Ilmiah Kajian Antropologi 1(2): 124 https:// doi.org/10.14710/endogami.1.2.124-135

Na'im, M. A. 2017. Hoaks Sebagai Konstruksi Sosial Untuk Kepentingan Politik Praktis Dalam Pilgub DKI Jakarta. Jurnal Darussalam: Jurnal Pendidikan, 
Komunikasi Dan Pemikiran Hukum Islam, 8(2), 361-370. https://doi. org/10.30739/darussalam.v8i2.107

Nurlaili, S. 2009. Dimensi Metafisik Tradisi Grebeg Maulud Keraton Kasunanan Surakarta. Kudus: Maseifa Jendela Ilmu.

Rais, M. 2010. Hegemoni Elit Dalam Ritus Agama Lokal: Studi Keberagamaan Masyarakat Bugis Bone Sulawesi Selatan. El-Harakah (Terakreditasi), 12(2), 98-119. https://doi.org/10.18860/el.v0i0.446

Syukri, A. 2011. Amalan Menghadiahkan Pahala Kepada Mayit Dalam Perspektif Fiqh Muqaran (Studi Komperatif Antara Pendapat Ulama Mazhab yang Mendukung Dan Menolaknya). Riau :Universitas Islam Negeri Sultan Syarif Kasim.

Wardana, I. B. K. 2018. Konsep Sedekah Menurut Yusuf Mansur. Jakarta: UIN Syarif Hidayatullah.

Zainuddin. 2013. Teori Konstruksi Sosial. UIN Maliki Malang: Tabloid Gema. 
